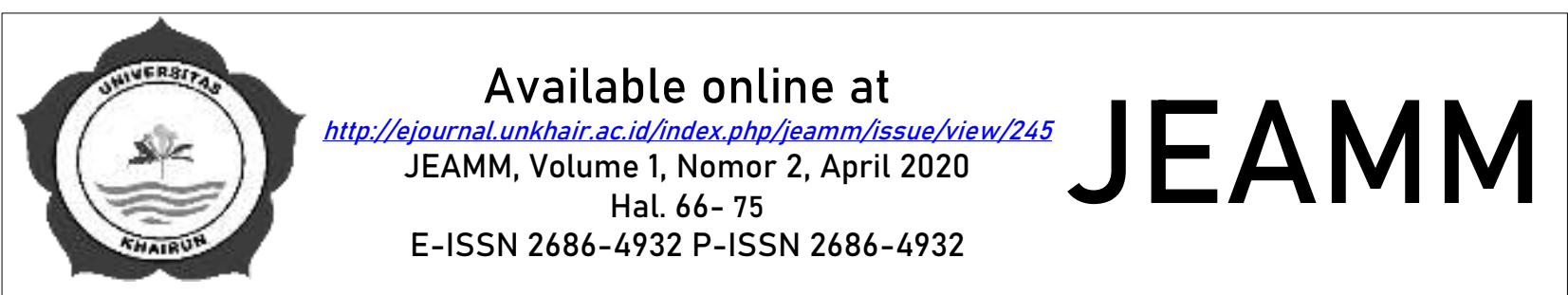

\title{
KONDISI SOSIAL EKONOMI DAN BUDAYA MASYARAKAT DESA WISATA BOBANEHENA KABUPATEN HALMAHERA BARAT
}

\author{
Nurlaila \\ Fakultas Ekonomi dan Bisnis Universitas Khairun \\ Email. lelafekon@yahoo.com
}

Dikirim, 12 Maret 2020

Revisi, 17 Maret 2020

Diterima, 29 Maret 2020

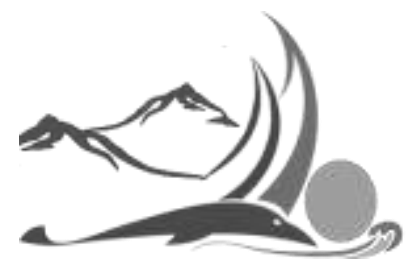

Jurnal Ekonomi, Akuntansi dan Manajemen Multiparadigma Volume 1, Nomor 2, April 2020

\begin{abstract}
ABSTRAK
Penelitian ini bertujuan untuk mengetahui kondisi sosial ekonomi masyarakat desa wisata Bobanehena Kabupaten Halmahera Barat. Kondisi sosial ekonomi masyarakat dilihat dari aspek pekerjaan, pendapatan, dan kondisi budaya masyarakat dilihat dari aspek tingkat pendidikan dan adat atau trdisi masyarakat. Jenis penelitian kualitatif, dengan jumlah informan sebanyak 7 orang yang merupakan masyarakat Desa Bobanehena. Pengumpulan data dilakukan dengan pembagian kuesioner dan wawancara mendalam oleh peneliti. Hasil penelitian menunjukkan bahwa jenis pekerjaan yang dimiliki oleh masyarakat Desa Bobanehena yaitu Petani, Nelayan dan (PNS), sebagian memiliki mata pencarian membuat kopra dan berdagang. Wilayah yang dikelilingi oleh laut menyebakan hampir sebagaian masyarakat mengantungkan kehidupan ekonomi sebagai nelayan, dengan tingkat pendidikan yang rendah Pekerjaan yang dimiliki oleh para informan rata-rata bukan pekerjaan tetap hal ini tentunya berpengaruh pada pendapatan yang diperoleh. Masyarakat masih kurang memahami akan pentingnya pendidikan. Budaya yang dianut masyarakat hingga saat ini yaitu budaya adat seatorang.
\end{abstract}

Kata Kunci: Sosial Ekonomi, Budaya Masyarakat, Pendapatan, Desa Wisata, Adat Seatorang

\begin{abstract}
This study aims to determine the socio-economic conditions of the Bobanehena tourism village community in West Halmahera Regency. The socioeconomic condition of the community is seen from the aspect of work, income, and the cultural condition of the community seen from the aspect of the level of education and custom or tradition of the community. This type of qualitative research, with the number of informants as many as 7 people who are Bobanehena Village community. Data collection was carried out by distributing questionnaires and in-depth interviews by researchers. The results showed that the types of jobs owned by the people of Bobanehena Village are Farmers, Fishermen and (PNS), some of whom have livelihood to make copra and trade. The area surrounded by the sea causes almost part of the community to depend on economic life as fishermen, with a low level of education. The work owned by the informants on average is not a permanent job, this certainly affects the income earned. The community still does not understand the importance of education. The culture adopted by the community to date is the seatorang traditional culture.
\end{abstract}

Key words: Socio Economic, Community Culture, Income, Tourism Village, Adat Seatorang 


\section{PENDAHULUAN}

Penelitian ini memiliki tujuan untuk menjawab masalah yang diajukan dalam rumusan masalah atau fokus penelitian yang sesuangguhnya peneliti dapat mengetahui kondisi sosial masyarakat dan Budaya Masyarakat di Desa Wisata Bobanehena dilihat dari aspek sosial ekonomi. Ciri masyarakat desa salah satu nya yaitu kehidupan yang sangat bergantung pada sumber pertanian dan kelautan sebagai sumber penghasilan utama. Kondisi sosial ekonomi masyarakat perdesaan sebagaian besar pada umumnya bermata pencaharian disektor pertanian dan kelauatan seperti perkebunan perikanan dan pembudidayaan ikan. Bagi para petani dan nelayan kehidupan ekonomi merupakan hal yang sangat penting untuk ditingkatkan. Kebutuhan ekonomi yang dimaksud adalah suatu upaya yang dilakukan manusia baik individu maupun kelompok dalam rangka memenuhi kebutuhan hidup akan sandang, pangan dan papan. Jika dilihat dari sisi sosial ekonomi masyarakat masih tergolong rendah.

Pertumbuhan kebutuhan manusia akan pariwisata menyebabkan sektor ini dinilai mempunyai prospek yang besar di masa yang akan datang. Hal ini karena sektor pariwisata mampu menghidupkan ekonomi masyarakat di sekitarnya, sektor pariwisata juga diposisikan sebagai sarana penting dalam rangka memperkenalkan budaya dan keindahan alam daerah terkait. Menurut Asyhar (2014), sektor pariwisata merupakan sektor yang potensial untuk dikembangkan sebagai salah satu sumber pendapatan daerah. Usaha memperbesar pendapatan asli daerah, maka program pengembangan dan pemanfaatan sumber daya dan potensi pariwisata daerah diharapkan dapat memberikan sumbangan bagi pembangunan ekonomi. Banyak negara di dunia menganggap pariwisata sebagai invisible export atas barang dan jasa pelayanan kepariwisataan dan dapat berpengaruh pada neraca pendapatan.

Desa Bobanehena merupakan salah satu desa dari 34 Desa yang ada di Kecamatan Jailolo Kabupaten Halmahera Barat dengan memiliki kode wilayah 82.01.01 Provinsi Maluku Utara. Dengan jumlah penduduk 1989 Jiwa dan 464 KK, dengan mata pencaharian masyarakat pada umumnya yaitu petani dan nelayan dan sebagian kecil adalah pegawai negeri sipil (PNS). Desa Bobanehena memiliki keindahan lautan dan pegunungan yang mempesona. Keberadaan masyarakat di desa Bobanehena tersebut dengan budaya yang kental akhirnya dapat merubah mindset untuk memiliki hasrat memajukan desanya walaupun membutuhkan proses dari tahun ke tahun. Kehidupan sosial masyarakat khusunya pemuda dikala belum dikenal desa wisata Bobanehena yaitu pemuda yang rawan akan kejahatan, terdapat pemuda yang suka mengkonsumsi minuman keras, perkelahian antar warga, tidak memiliki pendapatan untuk menopang perekonomian mereka. Masih terdapat masyarakat yang memiliki pekerjaan tidak tetap (serabutan), sebagian kecil penduduk setempat yang memiliki perkebunan namun lokasinya berada di desa lain.

Lokasi tersebut berada di Jailolo dengan kondisi yang sangat strategis perpaduan antara pantai yang begitu indah dimana terdapat berbagai biota laut yang bisa dimanfaatkan untuk snorking, renang dan lain-lain, sedangkan disatu sisi juga terdapat pemandangan pengunungan yang indah dan dapat dimanfaatkan bagi pencinta pendaki gunung. Lokasi ini pula juga berpotensi dalam hal mengunggulkan kenaeka ragaman kuliener khas daerah setempat, lokasi ini pula memiliki nilai sejarah yang dapat diabadikan oleh para wisatawan. Lokasi Bobahena adalah lokasi yang unik yang dapat dinikmati sekaligus dalam berwisata oleh para wisatawan karena tergabung di kondisi laut dan pegunungan yang sangat mendukung untuk dikembangkan menjadi tempat wistawan yang dapat lebih dikenal oleh masyarakat baik lokal, nasional maupun internasional.

Kehadiran Pantai Wisata Desa Bobanehena sejak tahun 2017 masyarakat Desa Bobanehena merupakan sebagian besar adalah Ibu rumah tangga dan tidak mempunyai 
pekerjaan sudah mulai beralih ke pekerjaan pedagang yang ada di lokasi wisata. Dengan adanya perkembangan fasilitas wisata dan semakin banyaknya pengunjung yang datang ke lokasi wisata karena banyak terdapat keindahan pantai dan kolam air panas untuk tempat berendam dan lain-lain, semestinya sudah ada perkembangan yang inovasi bagi masyarakat Desa Bobanehena untuk bisa tampilkan potensi-potensi daerah dan sesuatu yang berbeda dengan jiwa entrepreneurship dan bukan hanya sebagai pedagang makanan dan minuman saja. Berdasarkan hasil survei peneliti sampai saat ini terdapat 10 pedangan yang ada di lokasi wisata dengan jenis usaha yang sama yaitu berdagang makanan dan minuman, sementara pengunjung yang datang terdiri dari wisatawan lokal, nasional maupun internasional/mancanegara, belum lagi jika terdapat event-event yang ada di Jailolo maka pengunjung bisa mencapai ribuan dalam seminggu.

Desa Bobanehena memiliki potensi ekonomi dan sosial yang besar namun belum sepenuhnya dimanfaatkan secara maksimal untuk meningkatkan kesejanteraan masyarakat. Pengembangan desa sebagai sumber dalam kontribusi perekonomian kurang mendapatkan perhatian pemerintah. Desa wisata dapat menjadi salah satu cara untuk peningkatan kesejahteraan ekonomi dan sosial masyarakat namun belum sepenuhnya disadari oleh seluruh anggota masyarakat. Desa wisata Bobanehena memiliki potensi alam dan budaya untuk dapat menarik wisata, namun masih terdapat beberapa kekurangan seperti sumber daya manusia yang masih terbatas dari segi kualitas maupun kuantitas, juga masih belum adanya kesadaran sepenuhnya partisipasi dari masyarakat dalam kegiatan wisata. Masyarakat desa wisata Bobanehena memiliki hubungan sosial yang eksklusif antar warga desa yang seharusnya dapat lebih dijadikan sebagai modal sosial utama untuk semakin menarik minat wisatawan datang berkunjung. Hal ini sangat disayangkan jika tidak ada pengembangan mindset masyarakat setempat maka peluang untuk menjadikan desa wisata kedepan yang berinovasi tidak dapat terwujud dan kehidupan ekonomi masyarakat tidak ada perkembangan.

Desa Bobanehena memiliki potensi ekonomi dan sosial yang besar namun belum sepenuhnya dimanfaatkan secara maksimal untuk meningkatkan kesejanteraan masyarakat. Pengembangan desa sebagai sumber dalam kontribusi perekonomian kurang mendapatkan perhatian pemerintah. Desa wisata dapat menjadi salah satu cara untuk peningkatan kesejahteraan ekonomi dan sosial masyarakat namun belum sepenuhnya disadari oleh seluruh anggota masyarakat. Desa wisata Bobanehena memiliki potensi alam dan budaya untuk dapat menarik wisata, namun masih terdapat beberapa kekurangan seperti sumber daya manusia yang masih terbatas dari segi kualitas maupun kuantitas, juga masih belum adanya kesadaran sepenuhnya partisipasi dari masyarakat dalam kegiatan wisata. Masyarakat Desa wisata Bobanehena memiliki hubungan sosial yang eksklusif antar warga desa yang seharusnya dapat dijadikan sebagai modal sosial utama untuk semakin menarik minat wisatawan datang berkunjung. Berdasarkan latar belakang masalah dan identifikasi masalah di atas, perlu adanya pembatasan masalah yang akan diteliti. Oleh karena itu penelitian ini akan difokuskan pada perbedaan kondisi sosial dan Budaya masyarakat. Hal pokok yang akan diteliti dalam penelitian ini adalah jenis pekerjaan, tingkat pendapatan serta gambaran tingkat pendidikan. Fokus dalam penelitian ini adalah bagaimana kondisi sosial ekonomi masyarakat di Desa wisata Bobanehena?

\section{METODE PENELITIAN}

Penelitian ini adalah jenis penelitian kualitatif deskripstif. Data dalam penelitian ini dikumpulkan menggunakan beberapa cara, yaitu observasi secara terus menerus, wawancara mendalam, dokumentasi serta triangulasi data. Teknik analisis data yang digunakan di penelitian ini yaitu model analisis interaktif. Menurut Millias dan Huberman, 
(1992), yaitu terdapat tiga komponen yaitu reduksi data, penyajian data, serta penarikan kesimipulan. Data yang tidak terungkap melalui wawancara, dilengkapi dengan data hasil observasi lapangan secara partisipatif yang dilakukan rentang waktu pada bulan Juni sampai bulan Agustus Tahun 2019.

\section{HASIL DAN PEMBAHASAN}

Karakteristik informan digambarkan melalui tabel rekapitulasi karakteristik informan untuk memudahkan pembaca memahami karakteristik informan dalam penelitian ini.

Tabel 1. Karakteristik Informan

\begin{tabular}{|c|c|l|c|c|c|}
\hline No & Inisial & \multicolumn{1}{|c|}{ Asal } & Usia & $\begin{array}{c}\text { Pendidikan } \\
\text { Terakhir }\end{array}$ & $\begin{array}{c}\text { Jenis } \\
\text { Kelamin }\end{array}$ \\
\hline 1 & Is & Bobanehena Jailolo & 43 & Paket C & Laki-Laki \\
\hline 2 & SL & Bobanehena Jailolo & 40 & S1 & Laki-Laki \\
\hline 3 & SA & Bobanehena Jailolo & 34 & SMA & Perempuan \\
\hline 4 & NA & Bobanehena Jailolo & 42 & SMP & Perempuan \\
\hline 5 & TB & Bobanehena Jailolo & 39 & SMA & Perempuan \\
\hline 6 & AM & Bobanehena Jailolo & 23 & SMA & Laki-laki \\
\hline 7 & FU & Bobanehena Jailolo & 50 & SD & Perempuan \\
\hline
\end{tabular}

Wawancara dilakukan kepada 7 (tujuh) informan di lokasi penelitian yaitu Desa Wisata Bobanehena Kecamatan Jailolo Halmahera Barat. Informan kunci yaitu Kepala Desa yang dipilih masyarakat pada tahun 2015. enam (6) Infoman lainnya yaitu : Ketua kelompok Pokdarwis sadar wisata Desa Bobanehena yang diangkat sejak tahun 2017 dan 4 (empat) infoman adalah pedagang di lokasi wisata, 1 (satu) infoman adalah penjual karcis pintu masuk, 1 (satu) infoman adalah petugas cleaning service. Untuk mendapatkan informas peneliti melakukan kunjungan secara langsung ke lokasi dan melihat kondisi pengunjung dari hari jam kerja dan hari libur, hal ini bermaksud untuk melakukan tringulasi (validasi data). Memperkuat substansi data dilakukan lewat hasil wawancara dan observasi secara langsung.

Berdasarkan hasil wawancara mendalam bersama informan IS, hadirnya pantai wisata Bobanehena memberikan peluang bagi dirinya untuk mendapatkan pekerjaan tetap. Sehari-hari, IS hanyalah pekerja serabutan dan nelayan yang hanya bekerja secara musiman sampai akhirnya muncul ide bersama teman-temannya untuk membnetuk sebuah kelompok yang diberi nama Pokdarwis (Kelompok Sadar Wisata). IS terpilih sebagai ketua kolompok dan bertugas bersama teman-temannya serta masyarakat setempat membangun tempat wisata dan mempromosikannya. Dengan jalan itulah, IS kemudian dipilih sebagai kepala desa Bobanehena. IS mengakui bahwa terpilihnya dia sebagai kepala desa tentu membawa perubahan besari dari sisi ekonomi dirinya dan keluarga setelah sebelumnya dia harus bekerja keras sebagai nelayan dan pekerja serabutan. Dari sisi pendidikan, IS menjelaskan bahwa tingkat pendidikan menjadi salah satu faktor penting yang merubah kondisi ekonominya. Atas dorongan masyarakat, IS mengikuti program paket C karena untuk menjadi kepala desa, IS harus memiliki ijazah SMA atau setaranya. IS juga mengungkapkan bahwa berhasilnya program wisata yang ada di desa Bobanehena dipengaruhi oleh dijunjungnya adat atau tradisi masyarakat setempat. Hingga saat ini, masayakat hidup dalam bingkai adat seatorang (adat dan aturan) yang telah diwariskan dari zaman ke zaman oleh para leluhur. Hal ini terekspresikan dalam beberapa sikap, diantaranya adalah sikap gotong royong di antara anggota masyarakat dalam menyukseskan program wisatanya. 
Hadirnya desa wisata yang dijaga dengan adat seatoran ini telah meningkatkan kondisi perekonomian masyarakat, meningkatkan peran sosial sekaligus berhasil mereduksi $80 \%$ tingkat kenakalan remaja.

Sementara itu, menurut SL, sebelum dan setelah terwujudnya tempat wisata desa Bobanehena tidak memberi pengaruh yang signifikan terhadap kondisi ekonominya karena sehari-hari profesinya adalah seorang pegawai negeri sipil pada dinas kesehatan Kecamatan Jailolo. Di samping itu, SL juga menjabat sebagai sekretaris Pokdarwis sejak awal berdiri, dan di tahun 2014 hingga sekarang SL terpilih sebagai ketua Pokdarwis menggantikan IS. Menurut SL, pendapatannya sebagai pegawai sudah bisa mencukupi kebutuhan ekonominya dan ditunjang lagi dengan pendapatannya sebagai ketua Pokdarwis setiap bulannya. Dari sisi pendidikan, SL mengakui bahwa apa yang menajdi profesinya saat ini sudah mampu menjadi tumpuan ekonomi keluarga sehingga baginya desa wisata tidak terlalu bergantung pada pendidikan. Dalam konteks adat seatorang, SL berpandangan sama dengan IS bahwa masyarakat sangat menjunjung adat seatorang sebagai bagian dari kehidupan yang terlah diwarisi dari generasi ke generasi oleh para leluhur.

Informan lainnya, yaitu ibu SA juga memberikan penjelasan yang hampir sama dengan para informan sebelumnya. SA adalah seorang ibu rumah tangga yang sehariharinya berprofesi sebagai penjual nasi kuning di salah satu sekolah dasar (SD) di Bobanehana. Hadirnya wisata di desa Bobanehena memberikan peluang kepada SA untuk melakukan melakukan ekspansi usahanya dengan membuka rumah makan di area wisata. Setiap paginya, SA menyiapkan nasi kuning dagangannya. Sebagian ia tempatkan di area sekolah dasar, sisanya ia bawa ke rumah makannya yang baru. SA mengakui bahwa pendapatannya sejak hadirnya tempat wisata mengalami peningkatan, pasalnya usaha nasi kuningnya di area sekolah dasar tidak banyak memberi keuntungan karena harganya menuyesuaikan kemampuan siswa. Dengan demikian, rumah makan berkontirbusi besar dalam meningkatkan pendapatan SA. Dari sisi pendidikan, SA adalah seorang lulusan SMA. Beliau mengatakan bahwa pendidikan tidak berpengaruh dalam pekerjaan yang ia tekuni. Profesinya sebagai pedagang nasi kuning di sekolah dan tempat wisata tidak bergantung pada tingkat pendidikan yang dimiilikinya. Seperti informan lainnya, SA mengakui bahwa masyarakat di desa Bobanehena sangat menjunjung adat seatorang yang menjadi identitas mereka sejak dulu hingga sekarang.

NA, salah seorang informan wanita dalam penelitian ini juga memberikan informasi. Ibu NA sebelum hadirnya tempat wisata adalah seorang ibu rumah tangga yang mengandalkan penghasilan dari suaminya yang berprofesi sebagai petani tahunan. Memiliki tiga anak dan hanya mengandalkan suami membuat kehidupan ekonomi keluarga NA tergolong sulit. Namun, hal itu berubah sejak hadirnya tempat wisata di desa Bobanehena. NA menangkap peluang usaha yang cukup bagus yaitu dengan membuka warung di lokasi wisata pada bulan April 2018. Sejak saat itu, kondisi ekonomi NA dan keluarga mulai membaik. Di warung itu, NA menjajalkan dagangannya berupa pisang goreng dan air jahe dari pukul 11.00 siang WIT hingga malam hari. Jika ada festival yang digelar di lokasi tersebut, pendapatan NA bisa meningkat dari biasanya. Dari sisi pendidikan, NA hanyalah lulusan SMP. Baginya, tingkat pendidikan tidak berpengaruh pada pekerjaan yang dijalaninya saat ini. Baginya, siapapun bisa menjalani pekerjaan itu asalkan memiliki kerja keras dan keahlian. Masyarakat desa Bobanehena dalam penilian NA juga masih terus menjunjung adat seatorang yang telah diwariskan oleh para leluhur. Hal tersebut terejawantahkan dalam bentuk kebersamaan dan saling menghargai antar sesama. Jika ada salah seorang anggota masyarakat yang berhajat, yang lain akan turut berkumpul dan saling membantu. 
Informan selanjutnya adalah TB. Sama seperti NA, TB adalah ibu rumah tangga yang tidak memiliki pekerjaan sebelum ada tempat wisata di desa Bobanehena. Memiliki 3 anak, TB hanya mengandalkan suaminya yang bekerja sebagai nelayan dan pekerja serabutan. Hadirnya tempat wisata di desa memberikan peluang usaha yang sama kepada TB. Akhirnya, TB membuka warung di lokasi tempat wisata pada Januari 2019. Dari usaha itulah, TB merasakan bahwa kondisi ekonominya kian membaik. Dari sisi pendidikan, TB adalah lulusan SMA. Meskipun demikian, TB juga memberi pengakuan yang sama bahwa pendidikan tidak berpengaruh pada apa yang dia kerjakan saat ini. Berdagang secara sederhana dengan niat membantu ekonomi keluarga bergantung sepenuhnya pada kerja keras serta ketekunan. Karena itulah, bagi TB pendidikan tidak berkontibusi pada pekerjaannya dan kondisi ekonominya. TB mengungkapkan bahwa masyarakat di desa Bobanehena selalu menjaga apa yang menjadi tradisi leluhur sejak dulu hingga sekarang, kendatipun banyak yang pendidikannya masih sangat minim. Tradisi yang terus menerus dipupuk dan dirawat hingga saat ini adalah gotong royong dalam mengerjakan sesuatu.

Informan selanjutnya adalah $\mathrm{AM}$, seorang anak muda yang ikut merasakan perubahan kondisi ekonominya setelah adalahnya desa wisata. AM berusia 23 tahun, lulusan SMA yang saat ini bekerja sebagai cleaning service di tempat wisata sejak tahun 2017. Sebelumnya AM tidak memiliki pekerjaan tetap. Sehari-hari, AM hanyalah pekerja serabutan yang hanya bekerja jika ada permintaan, seperti memetik kelapa dan lainnya. Itu tidak cukup memenuhi kebutuhan ekonominya. Sekarang, profesi barunya turut memberikan dampak pada kehidupan ekonominya, apalagi untuk ukuran dirinya yang belum berkeluarga (single). Dari sisi pendidikan, AM mengakui bahwa pekerjaannya sekarang tidak membutuhkan level pendidikan yang tinggi. Dengan kata lain, pendidikan tidak punya pengaruh pada profesi yang dijalaninya saat ini, juga pada kondisi ekonominya. Profesi sebagai cleaning service bisa dilakukan oleh siapapun yang memiliki keinginan dan kerja keras. Dari aspek adat atau tradisi, AM mengakui hal yang sama dengan informan lainnya bahwa memang masyarakat di desa Bobanehena selalu merawat adat seatorang yang telah diwariskan secara turun-temurun oleh para leluhur.

Informan terakhir yang turut memberikan informasi adalah FU, soerang wanita lulusan SD yang turut merasakan dampak positif hadirnya tempat wisata di Bobanehena. FU membuka warung makanan di lokasi wisata pada bulan Juni 2019 dengan menjajalkan aneka menu seperti pisang goreng, kelapa muda, dan berbagai cemilan. Sebelum membuka warung tersebut, FU sehari-hari bekerja sebagai seorang pedagang ikan. Menurutnya, itu belum cukop memenuhi kebutuhan hidupnya. Sekarang, dengan berjualan di lokasi wisata, FU mengakui bahwa penghasilannya meningkat dari biasanya sehingga kehidupan ekonomi keluargapun jadi lebih baik. FU menegaskan bahwa pendidikan tidak punya kaitannya dengan profesi yang ia jalani dan kondisi ekonominya saat ini. Profesi seperti itu sama seperti lainnya, hanya membutuhkan kerja keras dan ketekunan. Dari aspek adat atau tradisi, FU menegaskan hal yang sama yaitu masyarakat di desa Bobanehena selalu menjunjung tinggi adat seatorang dan hal tersebut terekspresikan dalam banyak hal seperti gotong royong saat ada hajatan salah seorang warga. Ikhtisar hasil wawancara bersama para informan bisa dilihat pada tabel 2 . 
Tabel 2 Rangkuman Hasil Wawancara

\begin{tabular}{|l|l|}
\hline \multicolumn{1}{|c|}{ Pertanyaan } & \multicolumn{1}{|c|}{ Hasil Wawancara } \\
\hline $\begin{array}{l}\text { Jenis pekerjaan sebelum dan sesudah ada } \\
\text { tempat wisata Desa Bobanehena, pekerjaan } \\
\text { sampingan, dan pekerjaan tersebut sudah } \\
\text { menjamin kondisi ekonomi. }\end{array}$ & $\begin{array}{l}\text { Terdapat 2 informan yang memiliki } \\
\text { pekerjaan sebagai PNS dan 5 informan } \\
\text { bukan PNS. 1 Informan yang memiliki } \\
\text { pekerjaan sampingan }\end{array}$ \\
\hline $\begin{array}{l}\text { Pendapatan dari hasil pekerjaan tetap } \\
\text { maupun pekerjaan sampingan }\end{array}$ & $\begin{array}{l}\text { Rata-rata Infoman mengtakan pendapatan } \\
\text { pada pekerjaan sekarang sudah cukup } \\
\text { memuaskan dibandingkan pendapatan } \\
\text { sebelumnya, walaupun tidak semua meiliki } \\
\text { pendapatan dari pekerjaan sampingan }\end{array}$ \\
\hline $\begin{array}{l}\text { Tingkat pendidikan saat ini berpengaruh } \\
\text { pada kehidupan ekonomi }\end{array}$ & $\begin{array}{l}\text { 1 Informan yang mengatakan tingkat } \\
\text { pendidikan yang berpengaruh pada } \\
\text { pendapatan kehidupan ekonomi dan 6 } \\
\text { informan lainnya mengatakan tidak } \\
\text { berpengaruh }\end{array}$ \\
\hline $\begin{array}{l}\text { Adat atau tradisi yang dimiliki oleh } \\
\text { Masyarakat Bobanehena }\end{array}$ & $\begin{array}{l}\text { Rata-rata informan mengatakan adat yang } \\
\text { dianut oleh masyarakat Bobanehena yaitu } \\
\text { adat seatorang, masyarakat masih } \\
\text { memeiliki tradisi gotong royong saling } \\
\text { peduli antar sesame. }\end{array}$ \\
\hline
\end{tabular}

Kondisi sosial ekonomi adalah suatu kedudukan yang diatur secara sosial dan menempatkan seseorang pada posisi tertentu dalam masyarakat, pemberian posisi itu disertai pula dengan seperangkat hak dan kewajiban yang harus dimainkan oleh si pembawa status Kondisi sosial ekonomi menurut penelitian Maftukhah (2007) adalah kedudukan atau posisi sesorang dalam kelompok manusia yang ditentukan oleh jenis aktivitas ekonomi, pendapatan, tingkat pendidikan, umur, jenis rumah tinggal, dan kekayaan yang dimiliki. Sama halnya dengan Sumardi, Abdulsyani (2013), juga memberikan batasan tentang kondisi sosial ekonomi yaitu, Merupakan suatu kedudukan yang diatur secara sosial dan menempatkan seseorang pada posisi tertentu dalam sosial masyarakat. Pemberian posisi disertai pula dengan seperangkat hak dan kewajiban yang harus dimainkan oleh si pembawa status.

Desa Wisata Bobanehena merupakan salah satu desa yang berada di Kecamatan Jailolo Kabupaten Halmahera Barat dengan jumlah penduduk berdasarkan data statistik 2018 sebanyak 1989 Jiwa dan memiliki 464 KK, dengan mata pencaharian rata-rata masyarakat yaitu nelayan dan petani, namun sebagian kecil juga sebagai pegawai negeri sipil (PNS). Jumlah penduduk yang mendiami suatu wilayah akan berpengaruh pada kesejahteraan masyarakat apabila dihubungkan dengan jumlah pendapatan masyarakat. Menurut Informan Kunci IS yang merupakan Kepala Desa Bobanehena, sebagian besar masyarakat desa yang berusia produktif belum memiliki pekerjaan tetap dan tidak mempunyai penghasilan tetap, pekerjaan mereka juga kebanyakan masih serabutan.

Secara umum terdapat tiga jenis pekerjaan yang dimiliki oleh masyarakat desa Bobanehena yaitu Petani, Nelayan dan Pegawai Negeri Sipil (PNS), masyarakat juga sebagaian memiliki mata pencarian membuat kopra dan berdagang. Wilayah yang dikelilingi oleh laut menjadikan hampir sebagaian masyarakat mengantungkan kehidupan ekonomi sebagai nelayan. Kondisi alam yang ada di desa Bobanehena memiliki tanah yang berbatuan dan rawan gempah. Nelayan tradisional merupakan pilihan masyarakat dengan 
tidak menggunakan teknologi canggih dalam penangkapan ikan. Teknik penenagkapan ikan dilakukan dengan menggunakan jaring dan jerat ikan.

Tingkat pendidikan yang rendah menjadikan pemahaman masyarakat untuk memenuhi kebutuhan ekonomi juga berpengaruh. Pekerjaan yang dimiliki oleh para informan rata-rata adalah bukan pekerjaan tetap hal ini tentunya berpengaruh pada pendapatan yang diperoleh. Namun gaya hidup masyarakat yang bukan konsumtif membuat mereka menikamti kondisi ekonomi yang ada, hal ini terlihat dari rata-rata jawaban Informan terkait pendapatan mereka sangat menikmati apa yang mereka terima, demikian pula pekerjaan sebagai petani, kondisi tanah yang tandus dan berbatu menjadikan masyarakat hanya menaruh harapan pada tanaman buah pisang dan kelapa, itupun sering mengalami masalah dalam pertumbuhan jika terjadi gempa didaerah sekitar. Ada sebagian kecil masyarakat yang memiliki letak kebun umumnya yang jauh dari pemukimannya, hasil kebun dipenuhi untuk kebutuhan nabati.

Karakteristik kehidupan masyarakat desa juga nampak dengan adanya tata masyarakat dan ekonomi pertanian dan nelayan, hal ini yang membedakan dengan masyarakat kota. Secara umum yang dapat membedakan antara masyarakat desa dengan masyarakat kota adalah dalam usaha pemenuhan tuntutan kehidupan. Umumnya masyarakat desa yang berprofesi sebagai petani dan nelayan dapat memenuhi kebutuhan keluarga karena dapat memproduksi sendiri kebutuhan pangannya sekaligus dapat memenuhi kebutuhan lain.

Masyarakat yang mempunyai tingkat sosial ekonomi yang rendah cenderung memiliki tingkat pendidikan yang rendah pula. Masyarakat masih kurang memahami akan pentingnya pendidikan. Masyarakat masih beranggapan bahwa pendidikan bukan merupakan jaminan bisa hidup sejahtera, jauh dari kemiskinan. Dengan anggapan bahwa sekolah hanya membuang waktu dan biaya saja. Pendidikan dasar saja belum cukup untuk menunjang pembangunan yang sedang berlangsung, masih banyak masyarakat yang tidak berhasil menyelesaikan pendidikan dasar sampai dengan selesai.

Tingkat pendidikan masyarakat desa Bobanehena masih tergolong rendah, sebagian besar masih tamatan pendidikan sekolah dasar dan sekolah menengah pertama. Rendahnya tingkat pendidikan masyarakat desa Bobanehena menyebabkan kurangnya pemahaman tentang makna konservasi sumberdaya alam di masa yang akan datang, disamping itu dengan rendahnya pendidikan yang dimiliki sebagian besar masyarakat desa bobenehena berpengaruh pada kurangnya ketrampilan yang dimiliki. Dari hasil pengamatan peneliti daerah setempat memiliki penghasilan tanaman buah pisang dan buah kelapa, namun jiwa kreatifitas yang tidak dimiliki oleh masyarakat setempat menjadikan pengolahan buah-buah tersebut seperti pisang goreng dan pisang rebus yang dapat disantap setiap hari dan buah kelapa kering di jadikan sebagai kopra, hal ini juga terlihat oleh peneliti saat berkunjung pada lokasi desa wisata Bobanehena yang ada. Aktivitas perdagangan yang dimiliki penjual di area wisata yaitu minuman es kelapa muda, pisang goreng, aer jahe, dan makanan khas popeda pisang rebus dll.

Masih terdapat kegiatan ekonomi masyarakat desa Bobanehena yang cenderung memiliki sistem barter. Budaya yang dianut masyarakat hingga saat ini yaitu budaya adat seatorang, begitu besar peran tokoh adat setempat dalam memupuk adat seatorang. Menurut IS (Informan Kunci), untuk desa-desa yang lain yang ada di kecamatan jailolo adat seatorang sudah tidak kental dbandingkan dengan desa Bobanehena. Tradisi kebersamaan masih terjalin antar sesama warga. Masyarakat desa Bobanehena 100\% memeluk agama Islam. Tradisi gotong royong dan menghargai orang yang lebih dewasa masih terlihat di masyarakat desa Bobanehena. Budaya masyarakat desa Bobanehena juga masih terlihat dengan adanya paguyuban, sifat kegotong-royongan dan kekeluargaan. Kehidupan sosial 
masyarakat desa wisata Bobanehena terdiri dari interaksi sosial, nilai sosial, dan tingkat pendidikan.

Sedangkan gambaran kehidupan ekonomi masyarakat Desa Bobanehena ini terdiri dari kepemilikan rumah tempat tinggal, luasnya tanah garapan atau tanah yang dimilikinya. Mengenai kondisi sosial ekonomi, Arifin (2002) menjelaskan kondisi sosial ekonomi sebagai kaitan antara status sosial dan kebiasaan hidup sehari-hari yang telah membudaya bagi individu atau kelompok di mana analisis kondisi sosial ekonomi dan tingkat pendidikan masyarakat. kemudian ia juga menjelaskan pula bahwa dalam semua masyarakat di dunia baik yang sederhana maupun yang kompleks, pola interaksi atau pergaulan hidup antara individu menunjuk pada perbedaan kedudukan dan derajat atau status kriteria dalam membedakan status pada masyarakat yang kecil biasanya sangat sederhana, karena disamping jumlah warganya yang relatif sedikit, juga orang-orang yang dianggap tinggi statusnya tidak begitu banyak jumlah maupun ragamnya.

Kondisi sosial ekonomi masyarakat desa Bobanehena berdasarkan hasil penelitian dapat dilihat dari hasil wawancara terhadap 7 (tujuh) informan. Sebagaimana umumnya masyarakat pedesaan, sumber utama pemenuhan kebutuhan ekonominya adalah pada sektor pertanian dan kelautan, namun hasilnya tidak menjamin kebutuhan sehari-hari, itupun dilakoni oleh kaum lelaki sementara kaum perempuan masih memilih menjadi ibu rumah tangga. Hasil bumi yang diperoleh dari petani lebih dominasi yaitu buah Pala, Pisang dan Kelapa, namun tidak semua masyarakat desa Bobanehena mempunyai hak tunggal hasil bumi tersebut. Hasil wawancara dengan Informan juga menengaskan bahwa apa yang dilakukan sebagai petani itu termasuk petani tahunan, untuk itu banyak dari mereka yang memilih untuk bekerja sebagai serabutan.

Pekerjaan serabutan otomatis pendapatanpun tidak menetap, namun dengan adanya pantai wisata yang dibangun di desa Bobanehena, sebagian masyarakat yang ikut melakukan dagangan di lokasi tersebut dapat menikmati hasil dagangnya, menurut para informan dari wawancara setiap hari selalu ada pendapatan karena ada pengunjung yang datang baik lokal maupun ragional, demikian pula jika pada hari libur sabtu dan minggu pendapatan mereka juga meningkat, dan lebih mengembirakan lagi jika terdapat kegiatan wisata dan sebagainya oleh pemerintah setempat maka pegunjungpun lebih banyak yang datang. Biasanya pengunjung dari nasional maupun manca negara sering menginginkan adanya trdaisi lokal daerah yang ditampilkan seperti, tarian dana-dana yaitu tarian yang selalu ditampilkan di di pantai wisata Bobanehena dan joko kaha sebagai bentuk penyambutan tamu dari luar daerah dan atraksi khas daerah bambu gila dan penyajian makanan adat dengan ciri khas masak tanpa menggunakan air tetapi menggunakan bambo, kegiatan-kegiatan demikianlah yang lebih menambah pendapatan ekonomi masyarakat setempat dan kelestarian budaya masyarakat yang di jaga sehingga dapat menciptakan kesan kepuasan bagi pengunjung tutur Kepala Desa Bobanehena.

Penelitian ini sejalan dengan Baharinawati yang mana tingkat pendidikan yang relatif rendah mempengaruhi perekonomian keluarga dan pemahaman masyarakat terhadap konservasi kawasan dan kondisi sosial ekonomi dan budaya masyarakat sangat berpengaruh terhadap presepsi tentang keberadaan pertambangan nikel dan konservasi kawasan.

\section{SIMPULAN}

Hasil penelitian ini menemukan bahwa kondisi sosial ekonomi masyarakat desa Bobanehena tergolong rendah. Hal ini dapat dilihat dari jenis pekerjaan dan tingkat pendidikan masyarakat setempat. Masyarakat desa Bobanehana masih bergelut dengan pekerjaan sebagai petani dan nelayan. Sementara itu, tingkat pendidikan mereka juga masih 
tergolong rendah. Hal ini berimbah pada tingkat perekonomian mereka. Meskipun demikian, masyarakat desa Bobanehena masih memiliki adat seatorang serta budaya yang kuat dan kental dengan adanya paguyuban, sifat gotong royong dan kekeluargaan. Secara keseluruhan, kondisi sosial ekonomi masyarakat belum mengalami perubahan secara signifikan meskipun hidup di kawasan pantai wisata. Peningkatan jumlah wisatawan di pantai Bobanehena nyatanya belum mampu merangsang kreativitas masyarakat terhadap potensi kearifan lokal yang ada. Hanya terdapat beberapa warga yang memanfaatkan momentum desa wisata untuk merubah kondisi sosial ekonomi mereka. Hubungan antar masyarakat yang eksklusif menjadi modal utama masayarakat untuk bisa memperbaiki kondisi sosial ekonomi dengan menarik minat dan kunjungan wisatawan yang semakin banyak. Penelitian ini juga memberikan rekomendasi kepada pemerintah agar bisa memberikan perhatian serius kepada masyarakat di desa Bobanehena agar dapat memanfaatkan potensi wisata yang dimiliki untuk meningkatkan pendapatan mereka.

\section{DAFTAR PUSTAKA}

Arifin, Zaenal. 2002. Kondisi Sosial Ekonomi Petani Tebu di Desa Negara Batin Sungkai Selatan. Unila. Bandar Lampung

Abdulsyani. 2013. Sosiologi Skematika, Teori dan Terapan. Jakarta: Bumi Aksara

Asyhar Basyir. Pengaruh Sektor Pariwisata Terhadap Pertumbuhan Ekonomi (online). Tersedia di http://asyharnotes.blogspot.com/2014/11/pengaruh-sektorpariwisataterhadap.html. Diakses pada tanggal 24 Juli 2019.

BPS Kabupaten Halmahera Barat, Kecamatan Jailolo Dalam Angka -2018.

Maftukhah. 2007. Pengaruh Kondisi Sosial Ekonomi Orang Tua Terhadap Prestasi Belajar Siswa Kelas VII SMP n 1 Randudongkal Kabupaten Pemalang Tahun 2006/2007. Skripsi. Universitas Negeri Semarang

Meleong, Lexy. 2011. Metodologi Penelitian Kualitatif. Bandung: Remaja Rosda Karya

Miles, M. B. \& Huberman, M. (1992). Analisis Data Kualitatif. Jakarta: Penerbit Universitas Indonesia

Spillane, James J. 1987. "Ekonomi Pariwisata Sejarah dan Prospeknya", Yogyakarta: Kanisius

Sukirno, Sadono. 2000. Makro Ekonomika Modern, PT. Rasa Grafindo Persada : Jakarta.

Bahawati W. Hastanti. Rina. Kondisi Sosial Ekonomi Dan Budaya Masyarakat Sekitar Kawasan Konservasi: Studi Kasus di Pulau Gag, Raja Ampat, Papua Barat (online). Tersedia di https://media.neliti.com, diakses tanggal 26 Juli 2019.

Pradanang, Tri. 2017. Studi Eksplorasi Kondisi Sosial Ekonomi Masyarakat Desa Wisata Nglinggo, Desa Pagerharjo, Kecamatan Samigaluh, Kabupaten Kulonprogo. (online). Skripsi. Tersedia di https:/ / eprints.uny.ac.id, diakses tanggal 26 Juli 2019.

Baharinawati W. Hastanti dan R. Gatot Nugroho Triantoro. 2012. Kondisi Sosial Ekonomi dan Budaya Masyarakat Sekitar Kawasan Konservasi. Studi Kasus di Pulau Raja Empat (Online). Tersedia di http://www.reseachgate.net, diakses tanggal 26 Juli 2019. 